\section{Commentary: Building bridges with extracorporeal membrane oxygenation}

\author{
Waël C. Hanna, MDCM, MBA, FRCSC
}

In this issue of JTCVS Techniques, Hawkins and colleagues ${ }^{1}$ present a challenging case of iatrogenic tracheal injury after multiple intubation attempts. The patient had presented with respiratory compromise due to viral pneumonia, and the resultant loss of tidal volume due to the tracheal injury precipitated profound respiratory failure and acidosis. After transfer to the authors' institution, the patient was promptly placed on veno-venous extracorporeal membrane oxygenation (ECMO), which allowed for stabilization and normalization of acid-base status. At 12 hours after ECMO, the trachea was successfully repaired, and the patient was eventually able to transition back to normal health.

This case report is not the first to describe ECMO as a bridge for surgery. It has been described in patients with trauma, lung transplantation, and tracheal injury. However, this case report is unique inasmuch as ECMO was not the only bridge. The rapid transfer to a tertiary center was probably a key — and perhaps underrecognized — step in saving this patient's life. Delays in transfer could have resulted in irreversible lung and brain damage that might not have been salvageable. The decision to delay surgical repair after the patient was placed on ECMO was also a key element in this success story. The aggressive treatment of complications, necessitating repeat surgery, is another important link in the chain. As such, although ECMO provided a bridge to surgical repair, this bridge had multiple pillars.

\footnotetext{
From the Division of Thoracic Surgery, McMaster University, Hamilton, Ontario, Canada.

Disclosures: The author reported no conflicts of interest.

The Journal policy requires editors and reviewers to disclose conflicts of interest and to decline handling or reviewing manuscripts for which they may have a conflict of interest. The editors and reviewers of this article have no conflicts of interest.

Received for publication Aug 8, 2020; revisions received Aug 8, 2020; accepted for publication Aug 13, 2020; available ahead of print Aug 15, 2020.

Address for reprints: Waël C. Hanna, MDCM, MBA, FRCSC, St. Joseph's Healthcare Hamilton, 50 Charlton Ave E, Juravinski Tower, Suite T2105 F, Hamilton Ontario L8N4A6, Canada (E-mail: hannaw@mcmaster.ca).

JTCVS Techniques 2020;4:392

2666-2507

Copyright (C) 2020 The Authors. Published by Elsevier Inc. on behalf of The American Association for Thoracic Surgery. This is an open access article under the CC BY-NCND license (http://creativecommons.org/licenses/by-nc-nd/4.0/).

https://doi.org/10.1016/j.xjtc.2020.08.036
}

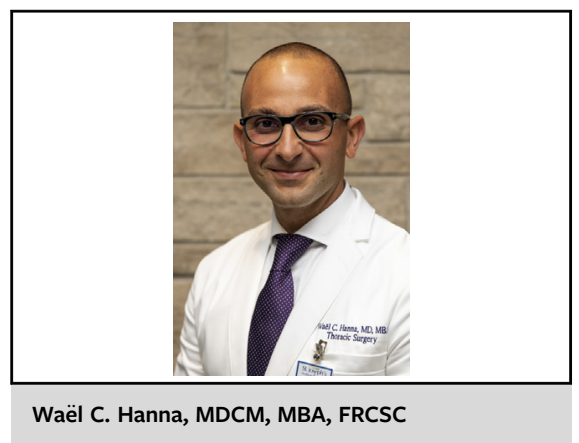

CENTRAL MESSAGE

ECMO is an important bridge

from ventilatory failure to

normal lung function and can

provide precious time for

tracheal injury.

This case demonstrates yet again that surgery is a multiteam sport, not a one-team sport. As we push the boundaries of what we can achieve in medicine, we find ourselves being operatives within a complex and interconnected system of disciplines and decisions, and building bridges becomes the best strategy for success.

\section{Reference}

1. Hawkins RB, Thiele EL, Huffmyer J, Bechtel A, Yount KW, Martin LW Extracorporeal membrane oxygenation for management of iatrogenic distal tracheal tear. J Thorac Cardiovasc Surg Tech. 2020;4:389-91. 